\title{
Impact of Low Cost Teaching Material on Students' Attitude towards Science at Secondary Level in Khyber Pakhtunkhwa Pakistan
}

\author{
Umar Khitab $^{1}$, Amir Zaman ${ }^{2}$ \\ Abdul Ghaffar ${ }^{3}$, Qasim Jan ${ }^{4}$
}

\begin{abstract}
This study aimed to investigate the impact of low cost teaching material on students' attitude towards science (Chemistry) at secondary level in Khyber Pakhtunkhwa Pakistan. This was an experimental study. Each group i.e. Experimental and control was consisted of 30 students of Grade 12 science stream. To assess the impact of low cost teaching material on students' attitude towards science (Chemistry) a modified form of Test of Science-Related Attitudes (TOSRA) comprised of 29 items was used. The test was purely constructed on a Likert scale to measure the students' attitude towards Chemistry on the factors such as Behavior tendency to learn Chemistry, Liking for chemistry laboratory work, Liking for Chemistry theory lesson, Evaluation belief about Chemistry, Leisure interest in science and the Enjoyment of Chemistry. Quantitative data were analyzed using t-test through Statistical Package for Social Sciences (SPSS). The main findings of the study indicated that students in the experimental group taught through activity with low cost materials showed significantly greater attitude towards science (Chemistry) than the control group.
\end{abstract}

Keywords: Science Education, Attitude towards Science, Low Cost Material

\section{Introduction}

The civilization of the world owes a great debt of gratitude to modern scientific inventions and discoveries whose stamp is clearly visible in every walk of life. The revolution brought about in the world by this scientific invention is highly commendable. Developed countries have made a wonderful progress because of their scientific education which has enabled them to utilize their material resources. It is now impossible for nations to remain isolated from another. They want to develop the scientific environment to keep their students on the right track to understand their physical environment. According to

\footnotetext{
${ }^{1}$ Abdul Wali Khan University Mardan, Email: ukhitab5@yahoo.com

${ }^{2}$ Abdul Wali Khan University Mardan

${ }^{3}$ Abdul Wali Khan University Mardan

${ }^{4}$ Abdul Wali Khan University Mardan
} 
Fathman et al, (1992) it is because of science education that a student can understand about his physical surroundings by developing a multicultural worldview of scientific phenomena. As science education is related to the teaching of science subjects such as Physics, Chemistry and Biology to the students, it revolves around the education career of the students.

Attitude towards science (Chemistry) may affect students' performance and academic achievement. To have a positive attitude and make the students creative thinkers are main goals of teaching science which ensure their better performance in chemistry.

Many studies conducted on students' attitude towards chemistry, e.g. Archibong (1992), Suydam, Marilyn and Higgins (1977), Hussain, et al. (2011) have found that teaching science with activity is more effective to learn science because this approach provides students with a tangible experience. In the education system, activity based teaching is focused on ideas and keeps the students directly engaged in laboratory work.

Science, especially chemistry is taught with activity based approach. But it is difficult for the third world countries like Pakistan, where the economic resources are very limited, to provide full teaching facilities to their students to develop scientific environment. Consequently, it is imperative to teach chemistry with low cost material in laboratories to keep students on scientific track. Therefore, the researcher tried his best to teach grade 12 science students with low cost teaching material to investigate the impact of low cost teaching materials on students' attitude towards science.

\subsection{Objectives of the Study}

There was a single objective of the study:

1. To investigate the impact of low cost teaching materials on students' attitude towards science (Chemistry).

\subsection{Hypothesis}

The null hypothesis was tested;

Ho: there is no impact of teaching through low cost materials on students' attitude towards Chemistry.

\subsection{Significance of the work}

This study is significant for several reasons. Firstly, this study is likely to guide the curriculum designers to incorporate low cost activities in the curriculum that makes the curriculum more effective, interesting and attractive for the students and science teachers. Secondly, this study is likely to help in building the capacity of science teachers to use and fabricate low cost activities 
by arranging different workshops and training that may help the effective teaching of science. Lastly, this study is likely to create a culture of low cost activity which will enrich our laboratory activities.

\section{Literature Review}

About the definition of attitude towards science Petty (1995) reached at the conclusion that all definitions for the attitude are within a consensus in which they are positive or negative thoughts, feelings or behaviors towards the objects around us. Therefore, different researchers defined attitude differently. According to Simpson and Oliver (1990) attitude is a concept that gives emotional trends relating to events or ideas. Therefore phrases "I like science" or "I enjoy science courses" enumerate as attitude. According to Osborne et al. (2003) attitude consists of different sub-constructs which ultimately gives rise to a person's attitude towards science.

One should not take the scientific attitude as attitude towards science. These are two different terminologies as Bennett (2003) makes a clear distinction between attitude towards science and scientific attitude. According to him, attitude towards science is linked to the views and images that the individual develops about science as a result of interaction with different situations, while the term scientific attitude is linked to the ways of thinking or scientific method, which covers the skills and is related to the undertaking of practical work. Gardner (1988) mentioned two categories about the broad nature of attitude i.e. attitude towards science that is related to interest in science. Simply, attitude towards science means like or dislike of any things related to science. The second category is "scientific attitude" which is a scientific process (open mindedness, objectivity, honesty). In the words of Yara (2009) attitude towards science denotes interest or feeling towards studying science. It is the students' disposition towards liking or disliking science. Gardner (1988) defines attitude as "a learned predisposition to evaluate in certain ways objects, people, actions, situations or propositions involved in learning science". (p. 34)

Developing positive attitudes towards science is one of the key goals for teaching and learning sciences Malik et al. (2010) conducted a study on the Effect of Problem solving teaching strategy on $8^{\text {th }}$ Grade students' attitude towards Science. The study was conducted with 60 students 30 in each experimental and control group at a public high school in Islamabad. A scale regarding attitude towards science learning (AtSL) with Cronbach's alpha 0.86 was administered to the students of both experimental and control groups. It was concluded that student in experimental group made a positive improvement in attitude towards science learning as compared to students in the control group. Silay (2008) worked on the effects of directive and non-directive problem- 
solving on attitudes and achievement of students in a developmental science course. It was concluded that attitude became more positive in direct instruction. Miller (1961) and Morse (1995) found that students with positive attitude towards science had positive attitude towards their science teacher, science curriculum and science-classroom climate. Students' attitude towards science is more likely to influence the success in science courses.

In contrast to positive attitude towards science, there are negative attitudes as well. These negative attitudes have been documented in numerous studies for a number of years in relation to courses in research, statistics and mathematics (Adams \& Holcomb, 1986; Elmore \&Vasu, 1980; Wise, 1985). According to Wise (1985), Waters, Martelli, Zakrajsek, and Popovich, 1988) one of the main problems of these negative attitudes is that they have been found to serve as obstacles to learning. In turn, these negative attitudes have been found to be associated with poor performance in such courses (Elmore\& Lewis, 1991; Woelke, 1991; Zeidner, 1991). However, (Meece, Wigfield, \& Eccles, 1990) suggest that attitudes are actually mediators between past performance and future achievement.

There is a mixed finding of different researches about activity based teaching and attitude towards science. Akporehwe and Onwioduoki (2003) conducted a study and found out that the activity-based approaches have significant effects on students' attitudes with guided discovery approach being most facilitative. It was also shown that gender and the interaction between opposite gender and activitybased approaches were not significant. This gave an indication that other factors play great role in enhancing student's attitudes. Similarly, Townsend (2012) conducted a study to examine the impact/effect of activity based activities on students' attitude toward science. The researcher reported that not only the students' attitudes towards science improved, but confidence and understanding of science increased as well. Students had positive feelings towards science; even they did not choose it as their favorite subject. According to students, science was more enjoyable when activities and laboratories were a part of learning experience. A similar study has been conducted by Demircioglu, Gokhan and Ayas (2005) in Turkey to investigate the effect on the students' achievement and misconception of new teaching material developed for the unit" acid and base". Moreover, the students' attitudes towards chemistry were also explored. The results indicated that students in the experimental group had higher attitude toward chemistry. This showed that the implementation of the new material produced better results both in terms of achievement and attitude. According to Gnanadesikan (1997) the use of activities has invigorated our 
teaching and improved our attitude. Some students responded very positively to this, while others show negative response.

Another study was conducted by Townsend (2012) on the Effects of laboratory-based activities on student's attitudes towards science. The sample comprised of 40 fifth grade students who were taught science over a five month period on laboratory based activities. It was concluded that using labs/activities inspired and increased the understanding of science in fifth grade students which showed a positive attitude towards science.

Smist and Owen (1994) believe that chemistry attitudes are predicted positively by self-efficacy and through chemistry attitudes self-efficacy reduced indirectly chemistry laboratory anxiety. In other words, attitude towards chemistry served as a mediator in linking self-efficacy and chemistry laboratory anxiety. Student's attitudes towards chemistry are very important for their involvement in learning in laboratory as well as in classrooms. According to Bandura (1986) self-efficacy is one's belief in his/her capacity to perform a specific task. Individuals may assess their skills and capabilities prior to performing certain actions or activities. Bandura (1986) further added that if individuals have high self-efficacy to perform activities, they are more likely to attempt doing those activities and to develop positive attitudes toward them.

\subsection{Studies Related to Activities with Low Cost Materials}

Activities/experiments are important for active learning of the students, but it cannot be denied that these involve high cost/expenditure as most of the schools do not have well-equipped science laboratories. According to Khitab (2004) "most of the schools do not have separate chemistry laboratories and those having chemistry laboratories are not well equipped. However, it is certainly possible to design low cost activities and experiments using easily available materials to chemistry" (p. 13) According to Shafiq (Personal communication, March 2010) the use of those materials found around us as used and thrown away garbage, in science laboratories in an education institution is called low cost materials. Those activities which are performed in science laboratories with the help of low cost apparatus are called low cost activities. Low cost apparatus increases the capacity to observe. Similarly Ara (1998) stresses on the use of apparatus fabricated of low cost materials for the teaching of chemistry at the secondary level. She was of the opinion that for the development of scientific skills; illustration and provision of opportunities for scientific investigation the use of low cost materials are equally effective.

According to Ali and Papaiah (2015) "Sometimes the standard teaching aids may remain out of reach - may be due to any reason. Look around; quite possible one gets something from the surrounding, which may serve as a better 
teaching aid for the topic. A step further, perhaps he who is innovative, may prepare such an aid for the available materials from here and there, low cost-no cost teaching material is the term that refers to an offhand construction of a teaching aid with simple available materials costing little or nil. No-cost teaching material is mater is that which a teacher can use by carrying it from local sources. It may waste things which a teacher can use as a teaching aid. Low-cost teaching aids can be used in nursery, primary, middle, secondary and senior secondary schools" (p. 3)

A study was conducted by Sivakumar (2016) to find out the effectiveness of low cost teaching aids in teaching science. The sample consisted of 40 students in Control group and 40 students in Experimental group. It was concluded that the achievement scores of Experimental group students were higher than the Control group students. Teaching by using low cost teaching aids is more effective.

Another study was conducted by Khitab (2011) on the Development of Low Cost Learning Material for the teaching of Chemistry at Secondary Level. The sample consisted of 10 secondary school teachers and 100 students of class $10^{\text {th }}$. It was concluded that none of the science teachers could construct low cost material for the teaching of chemistry at the secondary level.

\section{Research Methodology}

Experimental method was used in this study and groups, i.e. control and experimental were randomly selected with the help of concerned teachers after obtaining demographic detail of participants.

\subsection{Population of the Study}

All the science students of government and private colleges of Khyber Pakhtunkhwa, studying at the $12^{\text {th }}$ grade, formed the population. The total number of Government, Non-Government Higher secondary schools and colleges is 1521; where 381166 Science students (Class 11th to 12th) were enrolled.

\subsection{Sample of the Study}

60 students of $12^{\text {th }}$ grade science stream were taken as a sample, i.e., 30 students for the control group and 30 students for the experimental group. The convenient sampling approach was adopted due to the nature of the study. And for such purpose the students enrolled in Oxford Education Academy Batkhela, Khyber Pakhtunkhwa Pakistan were taken as a sample for the following reasons.

1. This institution was accessible to researcher.

2. The Principal and staff of the Institution were cooperative.

3. This was a well-populated institution and students from far flung area were enrolled here. 


\subsection{Selection of Topics}

Keeping in view the objectives of the study, the researcher went through the chemistry book of grade 12 in order to select the topics to be taught in science classes. Mostly the selected topics were those that could be taught through activities with low cost materials. The selected topics were; (i) Preparation of Acetylene apparatus, (ii) Sodium Hydroxide, (iii) Hydrogen and Chlorine Gas by Brine solution in Nelson Cell (iv) The reactions of aluminum metal with HCI and $\mathrm{NaOH}$. (v) Examining the effect of heat on solubility, (vi) Total Hardness Determination in Water, (vii) Measurement of atmospheric pressure. One of the low cost apparatus has been given in Fig 3.1.

Figure 3.1

Low Cost Apparatus for the Preparation of Acetylene Gas

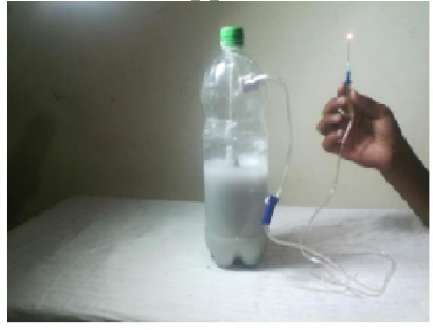

Presented Low Cost Apparatus

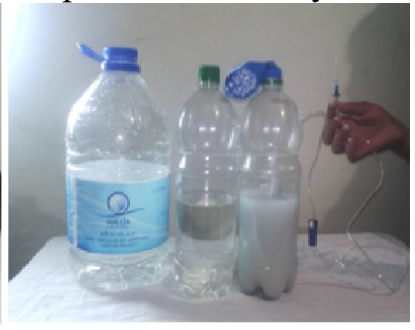

Modified Low Cost Apparatus

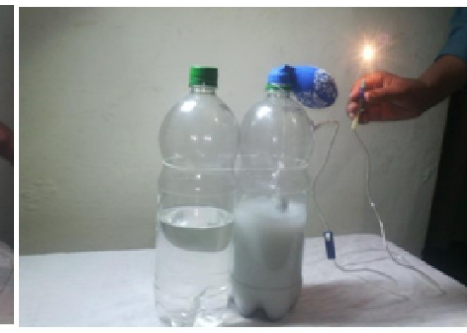

Developed Low Cost Apparatus

\subsection{Construction of Instrument}

Likert scale was constructed purely to measure the students' attitude towards chemistry on the factors such as the Behavior tendency to learn chemistry (BTLC), Liking for chemistry laboratory work (LCLW), Liking for chemistry theory lesson (LCTL), Evaluation belief about chemistry (EBAC), Leisure interest in science (LIS) Enjoyment of chemistry (EC)

$\mathrm{SD}=$ Strongly Disagree, $\mathrm{D}=$ Disagree, $\mathrm{NS}=$ Not sure, $\mathrm{A}=$ Agree, $\mathrm{SA}=$ Strongly Agree

Example;

\begin{tabular}{cllllll}
\hline $\begin{array}{c}\text { S. } \\
\text { No }\end{array}$ & $\begin{array}{l}\text { Statement of Attitude towards } \\
\text { chemistry }\end{array}$ & SD & D & NS & A & SA \\
\hline I & $\begin{array}{l}\text { Activity based teaching method } \\
\text { is the best way of learning } \\
\text { chemistry. }\end{array}$ & 1 & 2 & 3 & 4 & 5 \\
\hline
\end{tabular}




\subsection{Administration of Instrument}

The researcher taught the experimental group with low cost material and the control group with the lecture method for 17 days regularly. After seventeen days the modified test of TOSRA comprising 29 items was administered and timed for 90 minutes. As it was not a routine test, therefore, students were not familiar with it in their school and college life. Therefore, the researcher guided them. However, the respondents' response was quick and returned the test in no time. The collected data were analyzed using quantitative data analysis approach. Descriptive statistics, mean, the standard deviation and t- test was used to find the mean difference across groups along with effect size to find the strength of the mean difference.

\section{4. $\quad$ Results}

The modified form of TOSRA test was applied to treat both groups, i.e., control and experimental. The test consisted of six factors, i.e., the Behavior tendency to learn chemistry, Liking for chemistry laboratory work, Liking for chemistry theory lesson, Evaluation belief about chemistry, Leisure interest in science and enjoyment of chemistry.

To know the impact of teaching science through activities with low cost materials on students' attitude towards science (Chemistry), t-test was applied after treatment. The details are given in the table 4.1

Table 4.1

Comparison of Control and Experimental Groups in Attitude Towards Chemistry

\begin{tabular}{|c|c|c|c|c|c|c|c|}
\hline & Groups & Mean & $\begin{array}{l}\text { Std. } \\
\text { Deviation }\end{array}$ & $\begin{array}{c}\mathrm{t}- \\
\text { value }\end{array}$ & Df & $\begin{array}{l}\text { Sig } \\
\text { (two } \\
\text { tailed) }\end{array}$ & $\begin{array}{l}\text { Effect size } \\
\text { Cohen's d }\end{array}$ \\
\hline Pair & Control & 121.20 & 8.235 & 8.616 & & \multirow{3}{*}{.000} & \multirow{3}{*}{0.944} \\
\hline 1 & Experimental & 132.03 & 13.975 & & 29 & & \\
\hline \multicolumn{2}{|c|}{ Significance Level } & \multicolumn{2}{|c|}{$\mathrm{p}<0.05$} & & & & \\
\hline
\end{tabular}

Table 4.1 shows that there was a significant difference between the attitude towards science scores of the control and experimental group at 0.05 levels. Higher mean score of experimental group (132.03) shows that experimental group showed well in their TOSRA test. Higher standard deviation of experimental group means that there was more variation of score among students than the control group indicating that some students were more impressed by low cost activities than other fellows. To evaluate the mean difference further 
Cohen's D effect size was used and its values $(0.944>0.8$ Cohen effect size value) showed that a large effect size in case of experiment group.

Table 4.2

Comparison of Control and Experimental groups in Attitude towards Chemistry

\begin{tabular}{|c|c|c|c|c|c|c|c|}
\hline S No & Factors & Groups & Mean & Std. Dev; & $\mathrm{T}$ & Sig ; & $\begin{array}{l}\text { Effect size } \\
\text { Cohen's d }\end{array}$ \\
\hline \multirow[t]{2}{*}{1} & \multirow{2}{*}{$\begin{array}{l}\text { Behavior tendency to } \\
\text { learn chemistry }\end{array}$} & Control & 27.93 & 2.741 & 7.938 & .000 & \\
\hline & & Experimental & 31.01 & 3.998 & & & 0.96 \\
\hline \multirow[t]{2}{*}{2} & \multirow{2}{*}{$\begin{array}{l}\text { Liking for chemistry } \\
\text { theory lesson }\end{array}$} & Control & 15.47 & 1.737 & & & \\
\hline & & Experimental & 17.50 & 3.246 & 6.262 & .000 & 0.76 \\
\hline \multirow[t]{2}{*}{3} & \multirow{2}{*}{$\begin{array}{l}\text { Evaluation belief about } \\
\text { chemistry }\end{array}$} & Control & 24.90 & 2.568 & & & \\
\hline & & Experimental & 27.30 & 2.336 & 9.055 & .000 & 0.97 \\
\hline \multirow[t]{2}{*}{4} & \multirow{2}{*}{$\begin{array}{l}\text { Liking forchemistry } \\
\text { laboratory work }\end{array}$} & Control & 21.53 & 2.909 & & & \\
\hline & & Experimental & 24.10 & 2.537 & 7.289 & .000 & 0.94 \\
\hline \multirow[t]{2}{*}{5} & \multirow{2}{*}{$\begin{array}{l}\text { Lasure interest in } \\
\text { science }\end{array}$} & Control & 16.73 & 3.352 & & & \\
\hline & & Experimental & 19.37 & 2.385 & 8.137 & .000 & 0.91 \\
\hline \multirow[t]{3}{*}{6} & \multirow[t]{3}{*}{ Enjoyment of chemistry } & Control & 15.87 & 2.968 & & & \multirow[t]{2}{*}{0.55} \\
\hline & & Experimental & 17.60 & 3.286 & 2.344 & 000 & \\
\hline & & \multicolumn{2}{|c|}{$P<0.05$ Significant Level } & \multicolumn{2}{|c|}{$\mathrm{Df}=29$} & & \\
\hline
\end{tabular}

Table 4.2 shows that there was a significant difference between the students' behavior tendency to learn chemistry, factor of attitude towards science, scores of the control and experimental group at 0.05 levels. Higher mean score of experimental group (31.47) shows that the experimental group showed well in their behavior tendency to learn chemistry. Higher standard deviation of experimental group means that there was more variation of score among students than the control group indicating that some students were more impressed by low cost activities than other fellows. Higher mean score of second factor, Liking for chemistry laboratory work of experimental group (17.50) shows that experimental group showed well in their attitude towards science. Higher standard deviation of experimental group means that there was high variation of score among students than the control group, which indicates that students were more impressed by low cost activities than other fellows and liked to work in chemistry laboratory with low cost activities. Similarly, the mean scores $(\mathrm{M}=27.93,15.47,24.10,19.37$ and 17.60) of Liking for chemistry theory lesson, Evaluation belief about chemistry, Laisure interest in science and enjoyment of chemistry respectively of experimental group show that experimental group showed well in their TOSRA. The standard deviations of these factors were also higher in the experimental group which showed that the students were impressed 
by low cost activities. To elaborate the difference further Cohen's D effect size was also calculated as the Table 2 shows a large effect size in factors of attitude towards chemistry. Therefore, the null hypothesis, which claimed "there is no impact of teaching science through low cost materials on students' attitude towards science" of the study is therefore, rejected.

\section{Conclusion and Discussion}

The usage of the instrument of attitude towards chemistry in this study was to compare experimental and control groups on the basis of teaching chemistry through activities with low cost materials. The experimental group showed significant effect on the control group. This fact is evident from different strata where there was great difference between the score of experimental and control groups indicating positive attitude towards chemistry. The Cohen's D criteria $0.944>0.8$ favored to be large in the case of the experimental group. Standard deviation in the score of experimental group indicates that students of this group were more impressed by low cost activities than the other fellows. Furthermore, experimental group dominated over the control group in mean scores in all subscale of attitude towards chemistry i.e. Behavior tendency to learn chemistry,Liking for chemistry theory lesson, Evaluation belief about chemistry, Liking for chemistry laboratory work, Leisure interest in science, Enjoyment of chemistry with greater size effect ranging from 0.76 to 0.97 except enjoyment of chemistry with 0.55 favored medium size. Higher mean scores, greater size effect and higher standard deviation of experimental group indicate that students were more impressed by the teaching through activities with low cost materials as compared with the control group who received instruction trough a traditional method and liked to work in chemistry laboratory with low cost activities and had significantly higher performance accuracy in the test and higher attitude towards chemistry.

\section{Recommendations}

Following important recommendations were drawn on the basis of the findings and conclusion of this particular study between the experimental and control group performance and impact of teaching chemistry with low cost activities on attitude towards chemistry.

1. Teaching with low cost material improves the attitude of the students towards chemistry therefore, activity based teaching with low cost material is recommended for all types of students, whether they are high learners, slow learners or average learners as it increases students' attitude towards science.

2. Teaching with low cost material improves the behavior tendency of the students to learn chemistry of the students, therefore, it is recommended to design such low cost material in a curriculum that develops the behavior 
tendency of the students to learn chemistry which in turn leads to develop the positive attitude of the students towards chemistry.

3. There is a great impact of teaching through low cost material on chemistry laboratory work, therefore, the Government may formulate a policy to provide low cost apparatus and arrange refresher courses for the teachers in fabricating and the use of low cost equipment.

\section{References}

Adams, N. A. \& Holcomb, W. R. (1986). Analysis of the relationship between anxieties about Mathematics and performance, Psychological Reports, 59, 943-948

Akporehwe, J. N. \& Onwioduokit, F. A. (2013). Enhancing scientific attitudes through activity-based approaches, Nigerian Journal of Science and Science Education, 8(2)

Ali, S.L. \& Papaiah, M. (2015).Theme: Learning by doing Sub theme: Innovative use of low cost/no cost teaching learning materials International. Journal of Humanities and Social Science Invention, 2319-7722.

Ara, H. I. (1998). Activity based learning on low cost materials (equipment, glassware, Chemicals) in teaching chemistry at secondary school level in Pakistan (Unpublished Doctoral thesis). University of Peshawar, Peshawar, Pakistan.

Archbong, A.U. (1997). The relative effectiveness of activity based approach and lecture method on the Cognitive achievement of integrated science students. Journal of Science Teachers Association of Nigeria, 32(1), 30-37.

Bandura, A. (1986). Cognitive processes mediating behavioral change. Journal of Personality and Social Psychology, 35, 125-139.

Bailin, S. (2002).Critical Thinking and Science Education, Science \& Education, $11,361-375$.

Bennett, J. (2003). Teaching and learning science, New York: Continuum.

Demircioglu, H.I., Gokhan, D., \& Ayas, A. (2005). Conceptual change achieved through a new teaching program on acids and bases, Chemistry Education Research and Practice, 6(1), 36-51.

Elmore, P. B. \& Lewis, E. L. (1991, April).Statistics and computer attitudes and achievement of students enrolled in applied statistics: Effect of computer 
laboratory. Paper presented at the annual meeting of the American Educational Research Association, Chicago, IL.

Elmore, P. B. \&Vasu, E. S. (1980). Relationship between selected variables and Statistics achievement, Building a theoretical mode. Journal of Educational Psychology, 46, 215-222.

Fathman, A. K., Quinn, M. E., \& Kessler, C. (1992). Teaching science to English learners, Grades 4-8. Washington, DC: National Clearinghouse for Bilingual Education

Flower, J. L.(1987). Effect of the Problem Solving Approach on Achievement, Retention and Attitudes of Vocational Agricultural Student in Illinois. (Unpublished Doctoral thesis), University of Illinois at Urbana Champaign.

Gardner, H. (1988). Creative lives and creative works: A synthetic scientific approach. In R. J. Sternberg (Ed.), The nature of creativity (pp. 298-321). Cambridge University Press.

Gnanadesikan, M. (1997). An activity-based statistics course, Journal of Statistics Education, 5(2) 10-15.

Hafiz, M., Iqbal, M. \& Harrison, C. (2012). Students attitude towards science; A case of Pakistan. Pakistan Journal of Social and Clinical Psychology, 9(2), 3-9.

Hatice, B. (2012). Students' attitudes toward school chemistry, Asia-Pacific Forum on Science Learning and Teaching, 13(1), 1-15.

Hussain, S., Anwar, S. \& Majoka, M. I. (2011). Effect of peer group activitybased learning on Students' academic achievement in physics at secondary level. International Journal of Academic Research, 3(1), 940-944.

Khitab, U. (2004). A study on the causes of poor achievement of science students in the subject of Chemistry at secondary level in District DIR (L), (Unpublished M.Ed thesis), AIOU, Islamabad. Pakistan.

Khitab, U. (2011). The Development of Low Cost Learning Material for the Teaching if Chemistry at Secondary Level (Unpublished M.Phil thesis), City University of Science and Technology, Peshawar, Pakistan.

Malik, A.M., Shah, A.Z., Iqbal, Z \& Rauf, M.(2010). Effect of problem solving teaching strategy on 8th Grade students attitude towards science, Journal of education and practice, 1(3),16-27. 
Meece, J. L., Wigfield, A., \&Eccles, J. S. (1990). Predictors of math anxiety and its influence on young adolescents' course enrollment intentions and performance in mathematics. Journal of Educational Psychology, 82, 6070.

Millar, R. (1961).Beyond 2000: Science education for the future (The report of a seminar series funded by the Nuffield Foundation) London. London King's College: London, School of Education.

Morse, J. (1995). Approaches to qualitative-quantitative methodological triangulation, Nursing Research, 40, 120-123.

Osborne, J., Simon, S., \& Collins, S. (2003). Attitude towards science: A review of the Literature and its implications, International Journal of Science Education, 25(9), 1049-1079.

Petty, R. (1995). Attitude change, In A. Tesser (Ed.) Advanced social psychology. New York: McGraw-Hill.

Qudsia, R. (2003). Foundation of Education code.695, National Book Foundation (NBF), Rawalpindi: Art Printers.

Sily,I. (2008). Effects of problem-solving strategies teaching on the problem solving attitudes of cooperative learning groups in physics education, Journal of Theory and Practice in Education, 4(2), 253-266.

Simpson, R. D., \& Oliver, J. S. (1990).A summary of major influences on attitudes toward and achievement in science among adolescent students, Science Education, 74, 1-18.

Smist, J. M. \& Owen, S. V. (1994, April). Explaining science self-efficacy, Paper presented at the annual meeting of the American Educational Research Association. New Orleans, LA.

Sivakumar, R. P. (2016). Impact of low cost teaching aids in teaching science, Innovative thoughts. International research journal. 2(3) Available at;// orks.bepress.com/silvakumar/6/

Suydam, Marilyn, N., \& Higgins (1977). Activity-Based Learning in Elementary School Mathematics: Recommendations from Research. Information Reference Center (ERIC/IRC), The Ohio State University, 1200 Chambers Rd., 3rd Floor, Columbus, Ohio 43212. 
Townsend, L. A. (2012). The effects of laboratory-based activities on student attitudes towards science (Unpublished Master thesis), Montana State University, Bozeman, Montana

Waters, L. K., Martelli, T. A., Zakrajsek, T \&Popovich, P. M. (1988), Attitudes towards statistics: An evaluation of multiple measures. Educational and Psychological Methods, 48, 513-516.

Wise, S. L. (1985). The development and validation of a scale measuring attitudes toward statistics. Educational and Psychological Measurement, 45, 401-405.

Woelke, P. L. (1991). An examination of the factor structure of Wise's attitude towards statistics scale, Paper presented at the annual meeting of the American Educational Research Association, Chicago, IL.

Yara, O. P. (2009). Students' achievements towards mathematics and academic achievement in some selected secondary schools in south western Nigeria. European Journal of scientific Research. 36(3), 336-341.

Zeidner, M. (1991). Statistics and mathematics anxiety in social science students: Some interesting parallels. British Journal of Educational Psychology, 61, 319-328. 